\title{
The Lexicon of Transitive Verbs of Motion and the Asymmetry Between Goal and Source PPs
}

\author{
Simonetta Vietri \\ Dipartimento di Scienze Politiche e della Comunicazione \\ Università degli Sudi di Salerno \\ Via Giovanni Paolo II, 132, 84084 Fisciano SA, Italy \\ Tel: 39-346-965-4147Ｅ-mail: vietri@unisa.it
}

Received: October 10, 2020 Accepted: November 12, 2020 Published: November 29, 2020

doi:10.5296/ijl.v12i6.17808

URL: https://doi.org/10.5296/ijl.v12i6.17808

\begin{abstract}
The aim of this research is to verify the hypotheses on the asymmetry between source and goal PPs from both a syntactic and a cognitive point of view.

Nam's (2004) syntactic analysis shows that Goal PPs behave like adjuncts while Source PPs are internal arguments. Lakusta and Landau's (2005) cognitive experimental research reveals the tendency in speakers to express Goal paths over Source paths. Landau (2010) suggests that one of the causes of this asymmetry might be related to the lexicon: are there more attachment verbs than detachment verbs? If so, the more frequent exposure to goal paths would explain the goal bias.

For this purpose I have classified approximately 500 Italian transitive verbs of motion, the analysis of which revealed that verbs showing a goal pattern account for the vast majority in the lexicon, but also that goal verbs and source verbs behave differently with respect to such properties as transitive-intransitive pronominal alternation and subject alternation. The former is much more frequent with goal verbs, while the latter is applicable only to goal verbs.

Furthermore, the application of diagnostics like topicalization and pro-form confirms the syntactic asymmetry between source and goal PPs.
\end{abstract}

Keywords: Asymmetry, Goal verbs, Source verbs, Transitive-intransitive alternation, Subject alternation, Language/Thought 


\section{Introduction}

The aim of this paper is the empirical verification of Nam's hypothesis (2004) on the asymmetry between source and goal PPs, which was confirmed by the results of the experiments carried out by Lakusta and Landau (2005, 2012). In particular, Lakusta and Landau claim that the prominence of the goal with respect to the source, i.e. the goal bias, at the cognitive level may also be related to the possible presence in the lexicon of a higher number of verbs that require goal PPs rather than source PPs.

The classification and analysis of about 500 Italian transitive verbs of motion allowed me to verify the prominence of goal patterns in the lexicon, as hypothesized in Lakusta and Landau's research. The Appendix presents the six classes into which the Italian transitive verbs of motion are classified according to the principles of the Lexicon-grammar framework, as developed by Gross $(1975,1995)$ (Note 1).

Empirical analysis of the data allowed me (a) to numerically weigh the verbs that require the source and/or goal PPs, and (b) to highlight the syntactic properties that distinguish goal and source verbs. For example, transitive-intransitive pronominal alternation has a high applicability with caused motion verbs that take a goal PP and a low applicability with those that take a source PP. Furthermore, subject alternation is systematically applied only to goal verbs following a certain syntactic pattern.

This paper is organized as follows. Section 2 presents some of the more influential hypotheses on the representation of spatial expressions and the relationship between language and thought. I present Nam's hypothesis on the asymmetry between goal and source PPs, and Lakusta and Landau's claims on the goal bias. Section 3 provides an overview of the motion verb patterns, while sections 4 to 6 present a lexical-syntactic analysis of Italian transitive verbs of motion. Section 7 describes the results of the quantitative analysis carried out on Italian, while section 8 discusses the results of the diagnostics applied to the Italian data. Section 9 presents some conclusions.

\section{Linguistic and Psycholinguistic Hypotheses}

"Spatial cognition is central to human thinking, and spatial language is thus an important area of study, as it may reveal fundamental properties of human thought" (Levinson 2009). The literature devoted to spatial expressions is rich precisely because spatial cognition, despite being a central aspect of human thought, shows cross-linguistic variation.

Since the early 1970s, Talmy $(1972,1975)$ has stressed the linguistic variation of spatial expressions. He identifies the conceptual representation of motion events common to all languages and the way in which these representations are lexicalized in languages. In the following years, Talmy $(1985,1991,2000)$ developed the cross-linguistic typology of motion events that was the starting point of research in linguistics and cognitive science. Talmy identifies two main lexicalization patterns of motion events, he distinguishes between $s$-framed (satellite-framed) languages, such as Germanic languages (as well as Japanese and Korean) and v-framed (verb-framed) languages, such as Romance languages (and Chinese). 
$S$-framed languages encode manner in the verb and path in a satellite to the verb. $V$-framed languages encode path in the verb and manner in an adjunct clause.

The conceptual structure of motion events is universal while the linguistic structures are cross-linguistically variable. Jackendoff (1983) analyzes the universal conceptual representation of spatial expressions and, at the same time, accounts for the linguistic differences between English and Spanish (Jackendoff 1990: 223). There is a long-standing debate on cross-linguistic variation and the relationship between language and thought. Levinson (1996, 2009) and Evans and Levinson (2009) claim that linguistic patterns shape the conceptual patterns of speakers and, therefore, conceptual representations are not all universal. Slobin $(1996,1998)$ argues that "language may have an effect on the process of thinking for speaking" (Gennari et al. 2002) and highlights the critical aspects of Talmy's typological hypothesis. In the context of lexical semantics, Levin and Rappaport (2019) and Beavers et al. (2010) propose a way of overcoming Talmy's typology by developing new hypotheses on the relationship between linguistic variation and conceptual representation.

Extensive experimental cognitive research has been carried out on the relationship between the conceptual representations and linguistic patterns of spatial events. A number of scholars (cf., among others, Gennari et al. 2002, Papafragou et al. 2002, 2006, Papafragou and Selimis 2010) discuss Talmy's and Slobin's hypotheses. On the other hand, Lakusta (2005), Lakusta and Landau (2005, 2012), Lakusta et al. (2007, 2017), Lakusta and DiFabrizio (2017), Johanson et al. (2019) test the linguistic hypothesis proposed by Filip (2003), Nam (2004, 2012), and Markovskaya (2006) on the asymmetry between source and goal locatives. Georgakopoulos (2018) shows the prevalence of Goal paths in ancient Greek.

\subsection{Asymmetry Between Source and Goal: The Linguistic Evidence}

Nam (2004) argues in favor of syntactic and semantic asymmetry between goal PPs and sources PPs. He claims that source PPs are generated under the higher VP and are, therefore, adjuncts. Goal PPs behave like internal arguments and are generated under the lower VP. I will only take some of Nam's syntactic evidence into account; for further details the reader is referred to the original paper. The syntactic contrast between goals and sources is shown by topicalization ((1)-(6) are from Nam 2004): the source PP in (1) can move to the front, whereas the goal PP in (2) resists such a move. "This suggests that the Goal PP behaves more like a true complement of the verb send than the Source PP does" (Nam 2004: 11, par. 2.4):

(1) From Los Angeles John sent the letter to Chicago

(2) ??To Chicago John sent the letter from Los Angeles

Furthermore, the PP from the library in (3) can move over the durative adverbial for ten minutes, but the goal PP to the library in (4) is not allowed to move over the time-frame adverbial in ten minutes. Therefore "a Source PP is more ready to scramble with a temporal/aspect PP” (Nam 2004: 11, par. 2.4):

(3) a. He ran from the library for ten minutes

b. He ran for ten minutes from the library 
(4) a. He ran to the library in ten minutes.

b. ??He ran in ten minutes to the library.

Further evidence is shown by locative alternation, as in (5) and (6):

(5) a. John sprayed paint on the wall

b. John sprayed the wall with paint

(6) a. The woman embroidered flowers on the jacket

b. The woman embroidered the jacket with flowers

Nam (2004: 13, par. 2.5) claims that "locative PPs involved in such alternations are mostly Goal-type locatives [...] we claim that V-modifiers like Goal-type PPs allow locative alternation while VP-adjuncts like Source [...] hardly do".

Gehrke (2007: 86, par.1) argues that there is no such semantic and syntactic asymmetry and states "that the apparent differences between goals and sources derive from other factors". For reasons of space, I will not address Gehrke's discussion, and I refer the reader to the cited papers for further details.

\subsection{Asymmetry Between Source and Goal: Cognitive Evidence}

Despite Gehrke's criticism, the asymmetry between source and goal PPs is one of the most widely studied topics in cognitive experimental research, for example Lakusta (2005), Lakusta and Landau (2005, 2012), Regier and Zeng (2007), Papafragou (2010), Lakusta and DiFabrizio (2017), Johanson et al. (2019), and Do et al. (2019).

Landau (2010: 73) states that studies on spatial language can provide insights into "how the non-linguistic spatial systems shared by all species support the human ability to acquire and use language". As Landau (2010: 74-75) reports, there are two main hypotheses on spatial language. The author calls them the Space First and the Language First hypotheses. According to the Space First hypothesis, spatial language is learned early and easily because it reflects the representation already present in the non-linguistic spatial system prior to language learning. On the other hand, the Language First hypothesis states that spatial language reflects representations created by exposure to spatial expressions in one's native language. She also states that the latter hypothesis is "appealing because we know there are significant cross-linguistic differences in the way that languages express spatial relationships [...]" but it is not convincing since "it ignores the large attested similarities in the spatial concepts encoded by languages world-wide". Landau and Lakusta (2009), and Landau (2010) propose a third hypothesis where spatial language is a hybrid of spatial representation and language. I will not here discuss the details of the hybrid hypothesis, and I refer the reader to the cited papers for further details.

A great deal of experimental research investigating the relationship between spatial language and non-linguistic representations has been carried out by examining paths. Consider the sentences below (drawn from Landau 2010: 78): 
(7) The ball rolls to the bottom of the maze

(8) The ball rolls from the top of the maze

(9) The ball rolls from the top to the bottom of the maze

The PP to the bottom of the maze in (7) encodes the goal path, whereas the PP from the top of the maze encodes the source path in (8), and in (9) both source and goal paths are expressed.

Landau and Zukowski (2003), Lakusta and Landau (2005), Landau (2010), and Lakusta and Landau (2012) carried out experiments on paths, and the results pointed out an asymmetry between source and goal in the way events are described. There is a strong bias among children and adults to avoid expressing the source alone: the authors call it the goal bias (Landau 2010: 81, 83). The goal pattern also holds for such events as a transfer of possession (The book went/passed from Jane to John) or a change of state (The bear's ears changed/went from green to red) (Note 2).

Landau (2010: 89) explores the cause of this asymmetry and states that "the strong and absolute tendency for language to encode goal paths in preference to source paths may be rooted in the patterns of language to which the child is exposed. Specifically, there may be more verbs that take goal path expressions, and these may be represented in the language the child hears at a much higher frequency than verbs that take source path expressions". Similarly, Lakusta and Landau (2012: 538) raises the following questions "What is less clear in the case of goals and sources is whether there is a distinction between goal and source PPs at the grammatical level (as there is between the syntactic subject and object). Do goal and source PPs (e.g., into $\mathrm{x}$, out of $\mathrm{x}$, to $\mathrm{x}$, from $\mathrm{x}$ ) differ in their grammatical status? For example, are goals arguments and sources adjuncts of manner of motion verbs (e.g., 'run'))? Do goal PPs show up as core syntactic arguments more than source PPs (e.g., are there more verbs of attachment, such as "put", than detachment verbs, such as "remove")? If so, then the alignment of goal and source elements at the conceptual, pragmatic, and grammatical level may explain the mapping of goals and sources in language".

It is conceivable that the goal path is more prominent than the source path and also that agents are more prominent than patients when they are subjects (see Fillmore's thematic hierarchy (1968)) (Note 3). The prominence of goals is also evident at a pragmatic level: a goal event presupposes a source, but the opposite is not true. Lakusta and Landau (2012: 517, 538) states that if there are more verbs of attachment, such as put, than detachment verbs, such as remove, it is conceivable "that the path asymmetries observed in language stem both from the properties of non-linguistic event representations and constraints internal to language".

The analysis and classification of Italian transitive verbs of motion I present in this paper will make it possible to investigate the question raised by Landau and Lakusta (2012): Are there more verbs of putting than verbs of removing?

I will examine the syntactic patterns of Italian transitive motion verbs and check the frequency of the verbs that present (a) only PPs encoding the goal path, (b) only PPs 
encoding the source path, or (c) PPs encoding both source and goal paths. In the case of verb pattern (c), the analysis will also focus on verifying Nam's hypothesis on syntactic asymmetry between source and goal PPs. Even though the cited cognitive and linguistic research considers only goal/source PPs, I will analyze also those syntactic patterns where goals and sources are expressed by a direct object or by the noun in the denominal location verbs. This will provide a more complete picture on the expressions of goals and sources in the lexicon of Italian.

\section{The Argument Structure of Verbs of Motion}

Transitive verbs of motion can take only a direct object, as in (10), or a direct object and one or two prepositional phrases, as in (11)-(13), where mettere (put), svuotare (empty), and spostare (move) are defined as caused motion verbs:

(10) Maria percorse quel sentiero (Note 4)

'Maria walked that path'

(11) Maria mise i libri nella borsa

Maria put the books in=the bag

'Maria put the books into the bag'

(12) Maria svuotò la scatola dai libri

Maria emptied the box from=the books

'Maria emptied the box of the books'

(13) Eva spostò i libri dal tavolo sulla mensola

Eva moved the books from=the table on=the shelf

'Eva moved the books from the table onto the shelf'

Unaccusative verbs of motion can take a prepositional argument, as in (14), or two prepositional arguments, as in (15). Unergative verbs of motion may take a prepositional adjunct, as in (16):

(14) Il treno proviene da Milano

The train pro-comes from Milan (Note 5)

'The train comes from Milan'

(15) Maria arrivò a casa dall' università

Maria arrived at home from=the university

'Maria came home from university' 
(16) Maria camminò nel parco (Note 6)

Maria walked in=the park

'Maria walked in the park'

Some verbs may have both a directed motion use and a stative use, such as attraversare (cross) in (17)-(18) and andare (go) in (19)-(20):

(17) Maria attraversò il ponte

'Maria crossed the bridge'

(18) Spaccanapoli attraversa il centro storico

Spaccanapoli crosses the center historic

'Spaccanapoli crosses the historic center'

(19) Maria andò da casa sua a casa di Paolo

Mario went from home her to home of Paolo

'Maria went from her home to Paolo's'

(20) Quella strada va dalla cattedrale alla stazione

That street goes from $=$ the cathedral to $=$ the station

'That street goes from the cathedral to the station'

Locative complements are traditionally associated to PPs, although they can occur as the head of a direct object. Their interpretation depends on the verb they occur with. As stated by Guillet and Leclère (1992: 8) and Gross (1995) (Note 7), the toponym Roma denotes "the Romans" in (21), since the sentence sconfiggere un luogo (to defeat a place) is not licensed. The toponym Roma denotes a place in both (22) and (23), however only attraversare (cross) is a motion verb, though both sentences attraversare/fotografare un luogo (cross/photograph a place) are admitted:

(21) I Galli sconfissero Roma

'The Gauls defeated Rome'

(22) Gianni attraversò Roma

'Gianni crossed Rome'

(23) Gianni fotografò Roma

'Gianni photographed Rome'

The Wh-question introduced by (Preposition) Dove (where) is traditionally applied to distinguish locative complements. However, question (24) is inappropriate, even though 
attraversare (cross) is a motion verb in (22). It is the Wh-question introduced by Che cosa (What), as in (25), that is correct:

(24) - *Dove attraversò Gianni?

Where crossed Gianni?

‘*Where did Gianni cross?’

- *Roma

(25) - Che cosa/Quale posto attraversò Gianni?

What/Which place crossed Gianni?

'What place did Gianni cross?'

- Roma

In this paper I will examine only transitive caused motion verbs. I will analyze unaccusative motion verbs in further research.

\section{Transitive Caused Motion Verbs}

Caused motion verbs that take two complements enter two different patterns:

(26) Maria mise le valigie nel ripostiglio

Maria put the suitcases in=the closet

'Maria put the suitcases in/into the closet'

(27) Maria riempì il ripostiglio di valigie

Maria filled the closet of suitcases

'Maria filled the closet with suitcases'

In (26) the direct object denotes the located entity while the prepositional complement denotes the place/location. In (27) the direct object denotes the place/location while the prepositional complement denotes the located entity. In both sentence patterns the subject has the role of the causal Agent.

In (26) the direct object denotes the locatum, while the prepositional complement denotes the location. On the other hand, in (27) the direct object denotes the location, while the prepositional complement denotes the locatum (Note 8). Verbs like mettere (put) have a locatum-location pattern, while verbs like riempire (fill) have a location-locatum pattern.

\subsection{The Locatum-Location Pattern (Class A)}

Locatum-location verbs may take one PP that performs the thematic role of source in (28) and goal in (29), or two PPs denoting the source and the goal in (30): 
(28) Maria estrasse la pistola dalla fondina

Maria extracted the gun from=the holster

'Maria pulled the gun out of the holster'

(29) Maria inserì la pistola nella fondina

Maria inserted the gun in=the holster

'Maria put the gun into the holster'

(30) Lei trasportò la merce da Milano a Torino

'She transported the goods from Milan to Turin'

The locatum-location pattern includes 179 verbs: of which 118 take a goal PP, 29 take a source PP, and 32 take both a source and a goal PP. The data show that the majority of locatum-location verbs have a goal pattern (66\%), while source verbs are the least frequent $(16 \%)$. Verbs included in this class may enter transitive-intransitive pronominal alternation. As will be shown below, this property has a greater or a lesser applicability in relation to the type of PP. Before proceeding, I will give some details on transitive-intransitive alternation.

In Italian, a causative transitive sentence may alternate with an intransitive pronominal sentence that can be considered either a reflexive variant, as in (31b) and (33b), or an anticausative variant, as in (32b) and (34b). In the literature they are known as si-constructions. In Italian (and in Romance) reflexive and anticausative alternation shares some morphosyntactic properties, which can be summarized as follows. In examples (31)-(34), the transitive sentences in the (a) examples alternate with the unaccusative marked sentences in the (b) examples. The direct object in the (a) sentences appears in subject position in (b) unaccusative sentences, and the causal subject of the transitive sentences can be expressed as an optional prepositional phrase, provided the subject is not an Agent, as in (34b) (Note 9):

(31) a. Gianni piazzò il cecchino/la bomba sul tetto

Gianni placed the sniper/the bomb on=the roof

'Gianni placed the sniper/bomb on/onto the roof'

b. Il cecchino/*la bomba si piazzò sul tetto

The sniper/the bomb SI placed on=the roof

'The sniper/*the bomb placed himself/itself on/onto the roof' (Note 10)

(32) a. Gianni conficcò la pallottola nella gamba di Max

Gianni drove the bullet in=the leg of Max

'Gianni drove the bullet into Max's leg'

b. La pallottola si conficcò nella gamba di Max 
The bullet SI stuck in=the leg of Max

'The bullet stuck in Max's leg'

(33) a. La polizia disperse i manifestanti nella strade laterali

The police dispersed the protesters in=the streets side

'The police dispersed the protesters into the side streets'

b. I manifestanti si dispersero nelle strade laterali

The protesters SI dispersed in=the streets side

'The protesters dispersed into the side streets'

(34) a. Gianni/Il vento disperse i rifiuti nell' ambiente

Gianni/The wind spread the waste in=the environment

'Gianni/The wind spread the waste into the environment'

b. I rifiuti si dispersero nell' ambiente (con il vento/*con Gianni)

The waste SI spread in=the environment (with the wind/ with Gianni)

'The waste spread into the environment with the wind/*with Gianni'

Three types of hypotheses have been proposed in the literature: (a) causative alternation and reflexive constructions can both be explained by means of the same reflexivization process (Chierchia 2004), (b) reflexive constructions can be analyzed according to the same mechanism as causative alternation (Kayne 1975), and (c) the two constructions are independent of each other (Schäfer and Vivanco 2013). The on-going debate shows that the two types of si-constructions are morphosyntactically similar (Note 11).

Given their similarities, and since the object of this paper does not concern the analysis of pronominal forms, I will not distinguish between anticausative and reflexive variants, but I will consider them all generically as intransitive pronominal variants.

As stated above, the alternation shows a greater or a lesser applicability in relation to the type of path complements. The locatum-location pattern includes 118 goal verbs, 69 of which (58\%) participate in transitive-intransitive alternation, as in (31)-(34). The locatum-location pattern includes 29 source verbs, 9 of which enter alternation (1/3, 30\%), as in (35)-(37). Finally, 19 out of 32 source-goal verbs (about 60\%) participate in alternation, as in (38)-(39):

(35) a. L' umidità distaccò l' intonaco dalla parete

The humidity detached the plaster from=the wall

'The plaster detached from the wall'

b. L' intonaco si distaccò dalla parete (per l' umidità)

The plaster SI detached from=the wall (for the humidity) 
'The plaster detached from the wall (due to the humidity)

(36) a. Maria allontanò la ragazza dal marciapiede

Maria moved the girl from=the sidewalk

'Maria turned the girl away from the sidewalk'

b. La ragazza si allontanò dal marciapiede

The girl SI moved from=the sidewalk

'The girl turned away from the sidewalk'

(37) a. La corrente/Gianni allontanò la barca dalla banchina

The current/Gianni moved the boat from=the dock

'The current/Gianni pulled the boat away from the dock'

b. La barca si allontanò dalla banchina (per il vento)

The boat SI moved away from=the dock (for the wind)

'The boat left the dock (due to the wind)'

(38) a. Gianni trasferì Maria da Roma a Milano

Gianni moved Maria from Rome to Milan

b. Maria si trasferì da Roma a Milano

Maria SI moved from Rome to Milan

'Maria moved from Rome to Milan'

(39) a. Il vento spostò i sassi dalla spiaggia sulla strada

The wind moved the stones from=the beach on=the road

'The wind moved the stones from the beach onto the road'

b. I sassi si spostarono dalla spiaggia sulla strada

The stones SI moved from=the beach on=the road

'The stones moved from the beach onto the road

Table 1 shows that goal verbs (a) are the most numerous in the Italian lexicon and (b) permit transitive-intransitive alternation in the majority of cases:

Table 1. Verbs of class A

\begin{tabular}{lcc}
\hline $\begin{array}{l}\text { Locatum-Location pattern } \\
\text { Class A) }\end{array}$ & N. verbs & Transitive-Intransitive Alternation \\
\hline Source & 29 & $9(30 \%)$ \\
\hline Goal & 118 & $69(58 \%)$ \\
\hline Source and Goal & 32 & $19(60 \%)$ \\
\hline
\end{tabular}




\subsection{The Location-Locatum Pattern (Class B)}

The location-locatum pattern includes 29 verbs whose direct object may denote the goal in (40) and the source in (41), while the prepositional complement indicates the located entity:

(40) Maria riempì la casa di piante

Maria filled the house of plants

'Maria filled the house with plants'

(41) Maria svuotò il magazzino della merce

Maria emptied the warehouse of=the goods

'Maria emptied the warehouse of the goods'

These verbs may have a 'holistic' reading (Anderson 1971): they imply that the reference object occupies (partly or entirely) the place denoted by the direct object. This reading is absent for locatum-location verbs.

Goal verbs (22 out of 29) are more numerous than source verbs (7 out of 29), but in this case transitive-intransitive alternation applies equally to half the goal verbs (about 11 out of 22 verbs) and half the source verbs (about 4 out of 7 verbs), as in (42) and (43), respectively:

(42) a. Il vento riempì il giardino di foglie secche

The wind filled the garden of leaves dry

'The wind filled the garden with dry leaves'

b. Il giardino si riempì di foglie secche

The garden SI filled of leaves dry

'The garden filled with dry leaves'

(43) a. La polizia svuotò lo stadio dai tifosi

The police cleared the stadium from=the fans

'The police cleared the stadium of the fans'

b. Lo stadio si svuotò dei tifosi

The stadium sI cleared of=the fans

'The stadium was cleared of fans'

The data show that transitive-intransitive alternation is much less frequent when the source is expressed by a prepositional phrase (as in locatum-location verbs) rather than a direct object (as in location-locatum verbs). In other words, this type of alternation does not produce any differences in the frequency rate when goal and source are expressed by a direct object. 


\section{Macrothink}

International Journal of Linguistics

ISSN 1948-5425

2020, Vol. 12, No. 6

The property that characterizes location-locatum verbs is subject alternation (Levin, 1993: 79 and subsequent, Levin and Rappaport 1998). This type of alternation does not involve any change in transitivity: the noun of the prepositional phrase in (44) and (46) appears in subject position in (45) and (47), while the subject of (44) and (46) is obligatorily omitted in (45) and (47):

(44) Maria riempì la casa di ospiti/ piante

Maria filled the house of guests/plants

'Maria filled the house with guests/plants'

(45) Gli ospiti/Le piante riempirono la casa

'The guests/the plants filled the house'

(46) La polizia svuotò lo stadio di tutti i tifosi

The police emptied the stadium of all the fans

'The police emptied the stadium of all fans'

(47) I tifosi svuotarono lo stadio

'The fans emptied the stadium'

Subject alternation is systematically applicable to all goal verbs, while only 2 source verbs participate in such alternation. Table 2 summarizes the data:

Table 2. Verbs of class B

\begin{tabular}{lccc}
\hline $\begin{array}{l}\text { Location-Locatum pattern } \\
(\text { Class B })\end{array}$ & N. Verbs & $\begin{array}{l}\text { Transitive-Intransitive } \\
\text { Alternation }\end{array}$ & $\begin{array}{l}\text { Subject } \\
\text { Alternation }\end{array}$ \\
\hline Source & 7 & 4 & 2 \\
\hline Goal & 22 & 11 & 22 \\
\hline
\end{tabular}

\subsection{Locative Alternation (Class C)}

In Italian, as in other languages, locative alternation is a property of some caused motion verbs: a limited number of them enter both the locatum-location pattern and the location-locatum pattern, such as caricare (load), cospargere (sprinkle), disseminare (disseminate), spalmare (spread), spruzzare (spray), spolverare (dust), sgombrare (clear), as in the sentences below:

(48) L' esplosione disseminò tutta l' area di rottami

The explosion spread whole the area of debris

'The explosion spread the whole area with debris'

(49) L' esplosione disseminò i rottami su tutta l' area

The explosion spread the debris on whole the area 
'The explosion spread the debris onto the whole area'

(50) Maria sgombrò la soffitta dai libri

Maria cleared the attic from=the books

'Maria cleared the attic of the books'

(51) Maria sgombrò i libri dalla soffitta

Maria cleared the books from=the attic

'Maria cleared the books from the attic'

Unlike other languages, Italian is lexically poor in verbs that enter the locative alternation, with only 4 out of 14 alternating verbs taking a source PP (Note 12). The data confirm Nam's claim about locative alternation. Unlike location-locatum verbs, none of these verbs allows subject alternation, while transitive-intransitive pronominal alternation is allowed by almost all source verbs.

Table 3. Class $\mathrm{C}$ verbs

\begin{tabular}{lcll}
\hline $\begin{array}{l}\text { Locative alternation } \\
\text { (Class C) }\end{array}$ & N. Verbs & $\begin{array}{l}\text { Transitive-Intransitive } \\
\text { Alternation }\end{array}$ & Subject Alternation \\
\hline Source & 4 & 3 & 0 \\
\hline Goal & 10 & 6 & 0 \\
\hline
\end{tabular}

\section{Denominal Verbs: Locatum and Location Verbs (Classes D and E)}

One-complement transitive verbs include two types of denominal verbs: locatum and location verbs. In the examples below, imburrare (butter) and sminare (demine) are verbs whose base noun denotes the located entity, while the direct object denotes the goal in (52) and the source in (53) (Note 13):

(52) Maria imburrò la teglia

'Maria buttered the pan'

(53) Gli artificieri sminarono tutta la zona

The sappers demined whole the area

'The sappers demined the whole area'

They are called denominal locatum verbs (Class D) and are similar to location-locatum verbs (section 4.2), as in the examples below:

(54) Maria ricoprì/ spalmò la teglia di/con il burro

Maria covered/ smeared the pan of/with the butter

'Maria covered/smeared the pan with butter'

(55) Gli artificieri liberarono la zona dalle mine 
The sappers cleared the area from=the mines

'The sappers cleared the area of the mines'

These two different verb patterns show similarities and differences. In both cases the subject is a causal agent and the direct object has the role of source/goal with a holistic reading. Denominal locatum verbs contain a noun corresponding to the located entity, as in (52) and (53). For location-locatum verbs the located entity is expressed by the noun of the PP, as in (54) and (55).

Both types of verbs permit a PP introduced by $d i / c o n / d a$ 'of/with', where the noun has to be either a count noun in the plural or a mass noun. The count noun can be in the singular iff it denotes an entity that has an 'extension'. However, the PP is an argument with location-locatum verbs while it is an adjunct with denominal locatum verbs. In order to be permitted, the noun of the adjunct PP has to specify the nature of the base noun more precisely (Labelle 2000: 228, note 7, Jackendoff 1990: 165), as in (56):

(56) Gianni imburrò la teglia *di burro/ di margarina

Gianni buttered the pan of butter/of margarine

'Gianni buttered the pan *with butter/with margarine'

On the other hand, since location-locatum verbs are non-denominal verbs, there is no need to identify the noun of the prepositional phrase more precisely (see Vietri 2019b).

The locatum pattern includes 89 goal verbs (64\%) and 50 source verbs (36\%) out of a total of 139 , i.e. the majority of them denote the goal. Transitive-intransitive pronominal alternation is accepted by half the goal verbs (45 out of 89) and half the source verbs (26 out of 50), as in the examples (57)-(58), i.e. the same rate shown by location-locatum verbs. The results confirm that this type of alternation shows an asymmetry if goal and source are expressed by a prepositional phrase.

(57) a. Il vento/Maria riempì il giardino di foglie

The wind/Maria filled the garden of leaves

'The wind/Maria filled the garden with leaves'

b. Il giardino si riempì di foglie

The garden si filled of leaves

'The garden filled with leaves'

(58) a. La tempesta/Il cannone innevò la pista

The storm/ The snow-gun in-snow the slope

'The storm/snow gun covered the slope with snow'

b. La pista si innevò 
The slope SI in-snow

'The slope was covered with snow'

Section 4.2 pointed out that location-locatum verbs systematically participate in subject alternation only in the case of goal verbs, as in (59). Denominal locatum verbs show the same syntactic behavior, but only in 64 goal verbs out of 89 , as in (60):

(59) a. Maria riempì la casa di piante/ospiti

Maria filled the house of plants/guests

'Maria filled the house with plants/guests'

b. Le piante/gli ospiti riempirono la casa

'The plants/the guests filled the house'

(60) a. Maria ingioiellò il mantello di pietre preziose

Maria bejeweled the cloak of stones precious

'Maria bejeweled the cloak with precious stones'

b. Pietre preziose ingioiellarono il mantello

Stones precious bejeweled the cloak

'Precious stones bejeweled the cloak'

The lower frequency of subject alternation may be due to the fact that the locatum is incorporated in the verb. The data is summarized in Table 4:

Table 4. Verbs of Class D

\begin{tabular}{lllc}
\hline $\begin{array}{l}\text { Denominal locatum } \\
\text { verbs (Class D) }\end{array}$ & N. Verbs & $\begin{array}{l}\text { Transitive-Intransitive } \\
\text { Alternation }\end{array}$ & $\begin{array}{l}\text { Subject } \\
\text { Alternation }\end{array}$ \\
\hline Source & 50 & 26 & 0 \\
\hline Goal & 89 & 45 & 64 \\
\hline
\end{tabular}

Denominal location verbs (Class E) contain a noun denoting the source/goal, while the direct object denotes the located entity. The verbal prefix distinguishes the source from the goal (see also Note 13): it indicates the goal in (61), the source in (62), both the source and the goal in (63). The subject has the role of the causal Agent:

(61) Maria infornò

la torta

Maria in-oven.3SG.PST.IND the cake (Note 14)

'Maria baked the cake'

(62) Maria sfornò

la torta

Maria from-oven. 3SG.PST.IND the cake 
'Maria took the cake out of the oven'

(63) Maria rinvasò la pianta

'Maria repotted the plant'

Denominal location verbs are similar to caused motion verbs whose pattern is locatum-location (section 4.1), as (64)-(66):

(64) Maria mise la torta nel forno

Maria put the cake in=the oven

'Maria put the cake into the oven'

(65) Maria tolse la torta dal forno

Maria took the cake from=the oven

'Maria took the cake out of the oven'

(66) Maria trasferì la pianta da un vaso piccolo in un vaso grande

Maria transferred the plant from a vase small in a vase large

'Maria transferred the plant from a small vase to a large one'

In both sentence patterns, the subject is the causal agent while the direct object indicates the located entity. In denominal location verbs the Place is indicated by the base noun of the verbs in (61)-(63), while in the locatum-location verbs, as in (64)-(66), it is denoted by the noun of the prepositional complement(s).

Both types of verbs take a prepositional phrase that is an argument for locatum-location verbs, but an adjunct for denominal location verbs, because in the latter case the noun of the prepositional phrase is already contained in the verb. Moreover, the adjunct has to further specify the Place, otherwise the output sentence is unacceptable, as in (67):

(67) Lui infornò

la pizza *nel forno/forno a legna/microonde

Lui in-oven.3SG.PST.IND the pizza in=the oven/wood oven/ microwave

'He baked the pizza in the oven/wood oven/microwave'

The location class includes 84 verbs: 59 of which denote the goal, 22 the source, while only 3 denote both the source and the goal.

Section 4.1 showed that locatum-location verbs participate in transitive-intransitive alternation in $58 \%$ of the goal verbs and in about $1 / 3$ of the source verbs, as in (68):

(68) a. Lei rovesciò il vino sulla tovaglia

She spilled the wine on=the tablecloth

'She spilled the wine on the tablecloth' 
b. Il vino si rovesciò sulla tovaglia

The wine SI spilled on=the tablecloth

'The wine spilled on the tablecloth'

Denominal location verbs participate in transitive-intransitive pronominal alternation, only when they denote a goal as in (69), although the frequency rate is much lower than in locatum-location verbs, i.e. 12 out of 59 goal verbs. Again, the data show that this type of alternation is widespread when the goal is expressed by a prepositional phrase:

(69) a. Il capitano imbarcò i passeggeri

'The captain boarded the passengers'

b. I passeggeri si imbarcarono

The passengers sI boarded

'The passengers boarded'

No source verbs participate in Subject alternation either, while only 4 out of 59 goal verbs do. The data is summarized in Table 5:

Table 5. Verbs of Class E

\begin{tabular}{lccl}
\hline $\begin{array}{l}\text { Denominal location } \\
\text { verbs (Class E) }\end{array}$ & N. Verbs & $\begin{array}{l}\text { Transitive-Intransitive } \\
\text { Alternation }\end{array}$ & $\begin{array}{l}\text { Subject } \\
\text { Alternation }\end{array}$ \\
\hline Source & 22 & 0 & 0 \\
\hline Goal & 59 & 12 & 4 \\
\hline Source and Goal & 3 & 0 & 0 \\
\hline
\end{tabular}

\section{Non-denominal One-Complement Transitive Verbs (Class F)}

In the Italian lexicon there are some non-denominal transitive verbs whose direct object denotes the source in (70), the goal in (71), a passage in (72), a median in (73):

(70) La popolazione evacuò la città

'The population evacuated the city'

(71) I tifosi invasero il campo

'The fans invaded the pitch'

(72) Maria attraversò/percorse il ponte

'Maria traversed/crossed the bridge'

(73) Il pilota sorvolò Parigi

The pilot over=flew Paris

'The pilot flew over Paris' 


\section{Macrothink}

The verbs lasciare (leave) and raggiungere (reach), besides the direct object, may take a prepositional phrase denoting the goal in (74) and the source in (75):

(74) Maria lasciò Milano per Parigi

'Maria left Milan for Paris'

(75) Maria raggiunse Londra da Roma

'Maria reached London from Rome'

As far as thematic roles are concerned, the source/goal verbs of this class are equivalent to unaccusative motion verbs. In both cases, the subject is the entity in motion and the complement denotes the source in (76)-(77), and the goal in (78)-(79):

(76) Il treno lasciò Roma

'The train left Rome'

(77) Il treno proviene da Roma

'The train comes from Rome'

(78) Maria raggiunse Londra

'Maria reached London'

(79) Maria giunse a Londra

'Maria arrived in London'

From a syntactic point of view, the source/goal is denoted by the direct object in the transitive verbs and by the prepositional complement in unaccusative verbs. Verbs and prepositions express directionality in unaccusative verbs, while with transitive verbs only the verbs denote the path. However, let us point out that a large number of transitive verbs are formed by a prefix that indicates a locative preposition (see Iacobini 2004: 101-) as in circum-navigare (circumnavigate), oltre-passare (go beyond), ra-ggiungere (reach), so-mmergere (submerge), sor-volare (fly over), trans-volare (fly across):

(80) Il pilota sorvolò Parigi

The pilot over=flew Paris

'The pilot flew over Paris'

(81) Il pilota volò sopra/su Parigi

'The pilot flew over/on Paris'

(82) Maria oltrepassò il ponte

Maria over=crossed the bridge

'Maria crossed over the bridge' 
(83) Maria passò oltre il ponte

'Maria crossed over the bridge'

(84) Maria circumnavigò l' isola

'Maria circumnavigated the island'

(85) Maria navigò intorno all’ isola

Maria sailed around at=the island'

'Maria sailed around the island'

The verb circumnavigare (circumnavigate) in (84) denotes a motion starting and finishing in the same place.

English also shows that verbs like enter (The bear entered the cave) and walk into (The bear walked into the cave) are considered equivalent: the meaning of into is incorporated into the meaning of enter (Jackendoff 1983, Zwarts 2006). Jackendoff (1983: 183, par. 9.5) states:

"In order to deal with the more general case, we must ask how a conceptual structure can be carved up into lexical items. The verb "enter" serves as a good preliminary example. "The dog entered the room" can be paraphrased by "The dog went into the room." Both sentences have the semantic structure [...] in which "the dog" is theme and "the room" is the reference object of the path. However, this structure is lexicalized differently in the two cases. [...]. In other words, the verb "enter" itself lexicalizes the path-and place-functions instead of leaving them to be overtly expressed by a preposition".

This class is very heterogeneous and includes 41 verbs: 14 of which denote a median place, 12 denote a goal, 8 indicate a passage, 4 denote the source, and only 3 denote both the source and the goal. Nevertheless, goal verbs are much more frequent than source verbs.

Transitive-intransitive alternation is permitted in few entries: 4 out of 12 goal verbs, and only 1 out of 4 source verbs. This rate confirms that verbs of this class are similar to unaccusative motion verbs, where alternation occurs very rarely. Table 6 summarizes the data:

Table 6. Verbs of Class F

\begin{tabular}{lccl}
\hline $\begin{array}{l}\text { One-complement } \\
\text { (Class F) }\end{array}$ & non denominal verbs & N. Verbs & $\begin{array}{l}\text { Transitive-Intransitive } \\
\text { Alternation }\end{array}$ \\
\hline Source & 4 & 1 \\
\hline Goal & 12 & 4 \\
\hline Source and Goal & 3 & \\
\hline Median & 14 & \\
\hline Passage & 8 & \\
\hline & $\mathbf{4 1}$ & $\mathbf{5}$ \\
\hline
\end{tabular}




\section{MInstitute"}

International Journal of Linguistics

ISSN 1948-5425

2020, Vol. 12, No. 6

\section{Data and Results}

Table 7 reports the overall quantitative data related to the transitive motion verbs examined in this paper. Considering only those verbs that denote either the source path or the goal path, it can be observed that goal verbs account for 310 out of 426 , i.e. $72 \%$. These data confirm the prominence of the goal pattern in the lexicon.

The low number of Italian source verbs participating in locative alternation confirms Nam's observation that this type of alternation concerns primarily goal verbs. The data is summarized in Table 7:

Table 7. Classes A to F

\begin{tabular}{llrrrrl}
\hline Class & & Source & Goal & Source/Goal & Median & Passage \\
\hline $\mathrm{A}$ & Locatum-location verbs & 29 & 118 & 32 & & \\
\hline $\mathrm{B}$ & Location-locatum verbs & 7 & 22 & & & \\
\hline $\mathrm{C}$ & Locative alternation & 4 & 10 & & & \\
\hline $\mathrm{D}$ & Denominal Locatum verbs & 50 & 89 & & & \\
\hline $\mathrm{E}$ & Denominal Location verbs & 22 & 59 & 3 & & \\
\hline $\mathrm{F}$ & One-complement Tran. & 4 & 12 & 3 & 14 & 8 \\
\hline & & $\mathbf{1 1 6}$ & $\mathbf{3 1 0}$ & $\mathbf{3 8}$ & $\mathbf{1 4}$ & $\mathbf{8 = 4 8 6}$ \\
\hline
\end{tabular}

The syntactic analysis of transitive motion verbs highlights that there is also an asymmetry between goal and source with regard to transitive-intransitive pronominal alternation and subject alternation. The former applies more frequently to goal verbs, while the latter applies systematically only to goal verbs.

As far as transitive-intransitive alternation is concerned, analysis of the data reveals that locatum-location goal verbs (mettere 'put') and denominal location verbs (infornare 'bake') are the majority that accept this property. On the other hand, location-locatum verbs (riempire 'fill') and denominal locatum verbs (imburrare 'butter') show that the source/goal pattern does not affect the frequency rate of transitive-intransitive pronominal alternation. Therefore, if the goal/source is expressed by a direct object, no asymmetry occurs.

\section{Asymmetry Between Goal and Source: Evidence From Italian}

As already stated in section 2.1, Nam (2004) points out that topicalization in sentences (86) and (87) shows the syntactic contrast between goals and sources. I obtain the same results on the Italian data. Let us consider the examples below:

(86) Il pilota lanciò i viveri dall' aereo sul villaggio

The pilot dropped the supplies from=the plane on=the village

'The pilot dropped the supplies from the plane onto the village'

(87) Luca trasportò la merce da Roma a Milano

Luca transported the goods from Rome at Milan 
'Luca transported the goods from Rome to Milan'

Topicalization produces the acceptable sentences (88)-(89), if applied to the source PPs, while it produces the dubious sentences (90)-(91) if applied to the goal PPs:

(88) Dall' aereo il pilota lanciò i viveri sul villaggio

From=the plane the pilot dropped the supplies on=the village

'From the plane the pilot dropped the supplies onto the village'

(89) Da Roma Luca trasportò la merce a Milano

From Rome Luca transported the goods at Milan

'From Rome Luca transported the goods to Milan'

(90) ??Sul villaggio il pilota lanciò i viveri dall' aereo

On=the village the pilot dropped the supplies from=the plane

'?? Onto the village the pilot dropped the supplies from the plane'

(91) ??A Milano Luca trasportò la merce da Roma

At Milan Luca transported the goods from Rome

'?? To Milan Luca transported the goods from Rome' (Note 15)

The application of further diagnostics, such as the pro-form replacement test lo+fare (in English this pro-form corresponds to do so), confirms that source and goal PPs behave differently. If a phrase must necessarily be deleted when replacing part of the verbal phrase with the pro-form, that phrase is an argument, otherwise it is an adjunct (see Schütze, 1995: 105 for pro-forms in English), as in the examples below:

(92) Lia mise gli abiti nella valigia stamattina, e Eva lo fece ieri

Lia put the clothes in=the suitcase this=morning, and Eva it did yesterday

'Lia put the clothes into the suitcase this morning, and Eva did so yesterday'

(93) *Lia mise gli abiti nella valigia, e Eva lo fece nell' armadio

Lia put the clothes in=the suitcase, and Eva it did in=the closet

'*Lia put the clothes into the suitcase, and Eva did so into the closet'

Let us apply the pro-form lo+fare to sentences (86)-(87). When replacing only the verb and the goal PP, the pro-form produces the dubious sentences (94)-(95). When replacing the verb and the source PP, the pro-form produces the ungrammatical sentences (96)-(97):

(94) ??Il pilota lanciò i viveri dall' aereo sul villaggio, e Max lo fece dall' elicottero 
The pilot dropped the supplies from=the plane on=the village, and Max it did from=the helicopter

'The pilot dropped the supplies from the plane onto the village, and Max did so from the helicopter'

(95) ??Luca trasportò la merce da Roma a Milano, e Lia lo fece da Napoli Luca transported the goods from Rome to Milan, and Lia it did from Naples 'Luca transported the goods from Rome to Milan, and Lia did so from Naples' (96) *Il pilota lanciò i viveri dall' aereo sul villaggio, e Max lo fece sulla spiaggia

The pilot dropped the supplies from=the plane on=the village, and Max it did on=the beach

‘*The pilot dropped the supplies from the plane onto the village, and Max did so onto the beach'

(97) * Luca trasportò la merce da Roma a Milano, e Lia lo fece a Torino Luca transported the goods from Rome to Milan, and Lia it did at Turin '*Luca transported the goods from Rome to Milan, and Lia did so to Turin'

In the sentences examined above, the Agent shares only the source with the located entity, as in (86), or both the source and the goal, as in (87). If the Agent shares neither the source nor the goal with the located entity, as in (98), the diagnostics gives us partially different results:

(98) Luca spostò i libri dalla mensola sulla scrivania

Luca moved the books from=the shelf on=the desk

'Luca moved the books from the shelf onto the desk'

Topicalization produces a grammatical sentence when moving the source PP to the front, as in (99), while the goal PP resists such a move in (100):

(99) Dalla mensola Luca spostò i libri sulla sedia

From=the shelf Luca moved the books on=the chair

'From the shelf Luca moved the books onto the chair' (Note 16)

(100) ??Sulla scrivania Luca spostò i libri dalla mensola

On=the desk Luca moved the books from=the shelf

'??Onto the desk Luca moved the books from the shelf' 
On the other hand, the pro-form lo+fare produces ungrammatical sentences, either applied to the goal PP as in (101) or to the source PP as in (102):

(101) * Luca spostò i libri dalla mensola sulla scrivania, e Lia lo fece dalla scatola

Luca moved the books from=the shelf on=the desk, and Lia it did from=the box

'*Luca moved the books from the shelf onto the desk, and Lia did so from the box' (102) *Luca spostò i libri dalla mensola sulla scrivania, e Lia lo fece sulla sedia

Luca moved the books from=the shelf on=the desk, and Lia it did on=the chair

'*Luca moved the books from the shelf onto the desk, and Lia did so onto the chair'

The sharing of source/goal between the Agent and the located entity affects the syntactic behavior of caused-motion verbs. Given these results, the syntactic status of source and goal PPs deserves further analysis, also taking into account the role of locative PPs in unaccusative motion verbs.

\section{Conclusions}

The asymmetry between goals and sources has been asserted from a linguistic perspective in Nam (2004) and from a cognitive perspective in Lakusta and Landau (2005, 2012). In particular, Landau (2010) hypothesized that the goal bias may be also related to the higher number of goal verbs in the lexicon, with the result that children are exposed to this type of verbs more frequently. Lakusta and Landau (2012: 538) states that if there are more attachment verbs, such as put, than detachment verbs, such as remove "then the alignment of goal and source elements at the conceptual, pragmatic, and grammatical level may explain the mapping of goals and sources in language".

In order to verify the quantitative presence of goal and source patterns in the lexicon, I classified and analyzed 486 Italian transitive verbs of motion and detected 6 classes of verbs. In the Italian lexicon, out of 486 transitive motion verbs 310 show the goal pattern, 116 show the source pattern, and 38 shows the source-goal pattern (Table 7). The data confirm the prominence of goal patterns. The availability of cross-linguistic data on this topic would provide further evidence to the fact that the goal bias may be related to the lexicon.

I have shown that transitive-intransitive pronominal alternation is much more frequent with goal verbs especially when the goal is expressed by a prepositional phrase. Further research needs to be carried out in order to determine whether this behavior is motivated or due to idiosyncrasies in the lexicon. Analysis of the data also showed that subject alternation is systematically applicable only to goal verbs. 


\section{Al Macrothink}

International Journal of Linguistics

ISSN 1948-5425

2020, Vol. 12, No. 6

I have checked the syntactic asymmetry in Italian by applying not only topicalization (as in Nam 2004) but also pro-form. The results confirm Nam's hypothesis on syntactic asymmetry between goal and source PPs. Nam claims that goal PPs are arguments while source PPs are not, however the syntactic status of such prepositional phrases (whether or not they are both arguments) deserves further analysis taking into account unaccusative motion verbs as well as manner-of-motion verbs. This is an important point at a cognitive level as Lakusta and Landau (2012: 538) points out: "Do goal and source PPs (e.g., into x, out of x, to x, from x) differ in their grammatical status? For example, are goals arguments and sources adjuncts of manner of motion verbs (e.g., "run')?

Moreover, the diagnostics highlight that the sharing of source/goal paths between the Agent and the located entity affects equally the grammaticality of the pro-form lo+fare whether applied to source or goal PPs. All these issues deserve future research in order to formulate an explanation.

\section{References}

Anderson, S. R. (1971). On the role of deep structure in semantic interpretation. Foundations of Language, 7, 387-396.

Beavers, J., Levin, B., \& Tham, S. W. (2010). A Morphosyntactic Basis for Variation in the Encoding of Motion Events. Journal of Linguistics, 46, 331-377.

Chierchia, G. (2004). A Semantics for Unaccusatives and its Syntactic Consequences. In A. Alexiadou, et al.. (Eds.), The Unaccusative Puzzle: Explorations of the Syntax-Lexicon Interface (pp. 22-59). Oxford-New York: Oxford University Press.

Clark, E., \& Clark, H. (1979). When nouns surface as verbs. Language, 55, 767-811.

Do, M., Papafragou, A., \& Trueswell, J. (2019). The Goal Bias in Language and Memory: Explaining the Asymmetry. In A. K. Goel, et al.. (Eds.), Proceedings of the 41st Annual Conference of the Cognitive Science Society (pp. 268-274). Montreal, QB: Cognitive Science Society.

Evans, N., \& Levinson, S. (2009). The Myth of Language Universals: Language diversity and its importance for cognitive science. Behavioral and Brain Sciences, 32(5), 429-448.

Filip, H. (2003). Prefixes and the Delimitation of Events. Journal of Slavic Linguistics, 11(1), 55-101.

Fillmore, C. J. (1968). The Case for Case. In E. Bach, \& R. Harms (Eds.), Universals in Linguistic Theory (pp. 1-88). New York: Holt, Rinehart, and Winston.

Folli, R. (2001). Two strategies to construct Telicity: A comparative analysis of English and Italian. Oxford University Working Papers in Linguistics, Philology and Phonetics, 6, 47-65.

Folli, R. (2008). Complex PPs in Italian. In A. Ashbury, et al.. (Eds.), Syntax and Semantics of Spatial P (pp. 197-220). Amsterdam/Philadelphia: John Benjamins. 


\section{MInstitute ${ }_{\text {Mnk }}^{\text {Macrothink }}$}

International Journal of Linguistics

ISSN 1948-5425

2020, Vol. 12, No. 6

Gehrke, B. (2007). Goals and Sources in event structure. In B. Los, \& M. Van Koppen (Eds.), Linguistics in the Netherlands (pp. 86-98). Amsterdam/Philadelphia: John Benjamins.

Gennari, S., Sloman, S., Malt, B., \& Tecumseh Fitch, W. (2002). Motion events in language and cognition. Cognition, 83(1), 49-79.

Georgakopoulos, T. (2018). A frame-based approach to the source-goal asymmetry, Synchronic and diachronic evidence from Ancient Greek. Constructions and Frames, 10(1), 61-97. Amsterdam/Philadelphia: John Benjamins.

Gross, M. (1975). Méthodes en syntaxe. Paris: Hermann.

Gross, M. (1995). La notion de lieu argument du verbe. In D. Gaatone (Ed.), Tendances récentes en linguistique française et générale, lingvisticae investigationes supplementa (20 pp. 173-200). Amsterdam/Philadelphia: John Benjamins.

Grossmann, M., \& Rainer, F. (2004). La formazione delle parole in italiano. Tübingen: Max Niemeyer Verlag.

Gruber, J. S. (1965). Studies in lexical relations. Doctoral dissertation. MIT: Cambridge, MA. Reprinted by Indiana University Linguistics Club, Bloomington. Reprinted 1976 as part of Lexical structures in syntax and semantics. New York: North-Holland Publishing Company.

Guillet, A., \& Leclère, C. (1992). La structure des phrases simples en francais, Les constructions transitives locatives. Genéve/Paris: Libraire Droz.

Iacobini, C. (2004). Prefissazione. In M. Grossmann, \& F. Rainer (Eds.), La formazione delle parole in italiano (pp. 97-126). Tübingen: Max Niemeyer Verlag.

Ikegami, Y. (1982). Source vs goal: A case of linguistic dissymmetry. In R. St. Clair, \& W. Von Raffler-Engel (Eds.), Language and Cognitive Styles: Patterns of Neurolinguistic and Psycholinguistic Development (pp. 292-308). Lisse: Swets and Zeitlinger.

Ikegami, Y. (1987). 'Source' vs. 'goal': A case of linguistic dissymmetry. In R. Dirven, \& G. Radden (Eds.), Concepts of case (pp. 122-146). Tübingen: G. Narr.

Jackendoff, R. (1983). Semantics and Cognition. Cambridge, Massachusetts: MIT Press.

Jackendoff, R. (1990). Semantic structures. Cambridge, Massachusetts: MIT Press.

Jackendoff, R. (2014). Genesis of a theory of language: From thematic roles (source) to the Parallel Architecture (goal). Unpublished manuscript. https://ase.tufts.edu/cogstud/jackendoff/papers/GenesisofPA.pdf

Johanson, M., Selimis, S., \& Papafragou, A. (2019). The Source-Goal asymmetry in spatial language: language-general vs. language-specific aspects. Language, Cognition and Neuroscience, 34(7), 826-840.

Kayne, R. (1975). French Syntax. Cambridge, Massachusetts: MIT Press. 


\section{MInstitute ${ }_{\text {Mning }}^{\text {Macrothin }}$}

International Journal of Linguistics

ISSN 1948-5425

2020, Vol. 12, No. 6

Labelle, M. (2000). The semantic representation of denominal verbs. In P. Coopmans, et al. . (Eds.), Lexical specification and insertion (pp. 215-240). Amsterdam/Philadelphia: John Benjamins.

Lakusta, L. (2005). Source and Goal asymmetry in non-linguistic motion event representations. Unpublished doctoral dissertation, The Johns Hopkins University.

Lakusta, L., \& DiFabrizio, S. (2017). And, the winner is a visual preference for endpoints over starting points on infants' motion event representations. Infancy, 22(3), 323-343.

Lakusta, L., \& Landau, B. (2005). Starting at the end: The importance of goals in spatial language. Cognition, 96, 1-33.

Lakusta, L., \& Landau, B. (2012). Language and memory for motion events: origins of the asymmetry between source and goal paths. Cognitive Science, 36, 517-544.

Lakusta, L., Muentner, P., Petrillo, L., Mullanaphy, M., \& Muniz, L. (2017). Does making something move matter? Representations of goals and sources in motion events with causal sources. Cognitive Science, 41, 814-826.

Lakusta, L., Wagner, L., O'Hearn, K., \& Landau, B. (2007). Conceptual foundations of spatial language: Evidence for a goal bias in infants. Language Learning and Development, 3(3), 179-197.

Landau, B. (2010). Paths in language and cognition: Universal asymmetries and their cause. In G. Marotta, et al. (Eds.), Space in Language. Proceedings of the Pisa International Conference (pp. 73-94). Pisa: Edizioni ETS.

Landau, B., \& Lakusta, L. (2009). Spatial language, spatial cognition: Origins, development, and interaction. Keynote address. In J. Chandlee, et al.. (Ed.), Proceedings of the 33th Boston University Conference on Language Development (pp. 1-23). Bookline, MA: Cascadilla Press.

Landau, B., \& Zukowski, A. (2003). Objects, motions, and paths: Spatial language in children with Williams syndrome. Developmental Neuropsychology, 23(1\&2), 107-139.

Levin, B. (1993). English Verb Classes and Alternations: A Preliminary Investigation. Chicago: University of Chicago Press.

Levin, B., \& Rappaport Hovav, M. (1998). Morphology and Lexical Semantics. In A. Spencer, \& A. Zwicky (Eds.), The Handbook of Morphology (pp. 248-271). Oxford/Malden: Blackwell.

Levin, B., \& Rappaport Hovav, M. (2019). Lexicalization patterns. In R. Truswell (Ed.), Oxford Handbook of Event Structure (pp. 395-425). Oxford: Oxford University Press.

Levinson, S. (1996). Relativity in spatial conception and description. In J. Gumperz, \& S. Levinson (Eds.), Rethinking linguistic relativity (pp. 177-202). Cambridge: Cambridge University Press. 


\section{Macrothink}

International Journal of Linguistics

ISSN 1948-5425

2020, Vol. 12, No. 6

Levinson, S. (2009). Space: Linguistic Expression. International Encyclopedia of the Social \& Behavioral Sciences. Elsevier.

Markovskaya, E. (2006). Goal-source asymmetry and Russian spatial prefixes. In P. Svenonius (Ed.), Nordlyd: Troms $\varnothing$ working Papers in Linguistics (Vol. 33, pp. 200-219). Troms $\varnothing$ : CASTL.

Mateu, J. (2017). Two types of locative alternation. In A. González, \& I. Navarro (Eds.), Verb Valency Changes, Theretical and typological perspectives (pp. 52-77). Amsterdam/Philadelphia: John Benjamims.

Nam, S. (2004). Goal and Source: Asymmetry in their syntax and semantics. Paper presented at the Workshop on Event Structure, Leipzig, Germany.

Nam, S. (2012). Syntax-semantics mapping of locative arguments. In R. Manurung, \& F. Bond (Eds.), Proceedings of the 26th Pacific Asia Conference on Language, Information, and Computation (pp. 1-8). Faculty of Computer Science, Universitas Indonesia.

Papafragou, A. (2010). Source-Goal asymmetries in motion representation: Implications for language production and comprehension. Cognitive Science, 34, 1064-1092.

Papafragou, A., \& Selimis, S. (2010). Event categorisation and language: A cross-linguistic study of motion. Language and Cognitive Processes, 25(2), 224-260.

Papafragou, A., Massey, C., \& Gleitman, L. (2002). Shake, rattle, 'n' roll: the representation of motion in language and cognition. Cognition, 84, 189-219.

Papafragou, A., Massey, C., \& Gleitman, L. (2006). When English proposes what Greek presupposes: The cross-linguistic encoding of motion events. Cognition, 98, 75-87.

Regier, T., \& Zheng, M. (2007). Attention to endpoints: A cross-linguistic constraint on spatial meaning. Cognitive Science, 31, 705-719.

Schäfer, F., \& Vivanco, M. (2013). Reflexively Marked Anticausatives Are Not Semantically Reflexive. In E. O. Aboh, et al. (Eds.), Romance Languages and Linguistic Theory 2013: Selected papers from 'Going Romance' (pp. 203-20). Amsterdam/Philadelphia: John Benjamins.

Schütze, C. (1995). Attachment and Argumenthood. MIT Working Papers in Linguistics, 26, 95-151.

Slobin, D. (1996). From "thought and language" to "thinking for speaking". In J. Gumperz, \& S. Levinson (Eds.), Rethinking linguistic relativity (pp. 70-96). Cambridge: Cambridge University Press.

Slobin, D. (1998). Verbalized events: a dynamic approach to linguistic relativity and determinism. Working Papers for the LAUD Symposium (pp. 107-138). Essen: Linguistic Agency University-GH Essen. 


\section{Macrothink}

International Journal of Linguistics

ISSN 1948-5425

2020, Vol. 12, No. 6

Talmy, L. (1972). Semantic structures in English and Atsugewi. Ph.D dissertation, Department of Linguistics, University of California, Berkeley.

Talmy, L. (1975). Semantics and syntax of motion. In J. Kimball (Ed.), Syntax and Semantics, IV (pp. 181-238). New York: Academic Press.

Talmy, L. (1985). Lexicalization Patterns: Semantic Structure in Lexical Forms. In T. Shopen (Ed.), Language Typology and Syntactic Description III: Grammatical Categories and the Lexicon (pp. 57-149). Cambridge: Cambridge University Press.

Talmy, L. (1991). Path to Realization: A Typology of Event Conflation. Berkeley Linguistics Society, 17, 480-519.

Talmy, L. (2000). Toward a Cognitive Semantics, II: Typology and process in concept structuring. Cambridge, Massachusetts: MIT Press.

Vietri, S. (2017). Usi verbali dell'italiano, Le frasi anticausative. Roma: Carocci.

Vietri, S. (2019a). I verbi di maniera del movimento in italiano. Studi Italiani di Linguistica Teorica e Applicata, 3, 567-595.

Vietri, S. (2019b). Locatum and Location verbs in Italian, A Lexicon-Grammar Analysis. Manuscript submitted for publication.

Zubizarreta, M. L., \& Oh, E. (2007). On the syntactic composition of manner and motion (Vol. 48). Cambridge, Massachusetts: MIT Press.

Zwarts, J. (2006). Event shape: Paths in the semantics of verbs. Paper presented at the workshop 'Geometrical Structure in Event Concepts', University of Konstanz, October 7, 2004 and at the Semantics Colloquium, Radboud University Nijmegen, November 23, 2004.

\section{Notes}

Note 1. In order to build the classification, I used some of the main Italian dictionaries (Devoto-Oli, Treccani, De Mauro, Zingarelli) which sometimes include examples of the pronominal constructions I analyze throughout the paper. In the event of any doubts on grammatical judgements, I also conducted web searches.

Note 2. Gruber (1965) was the first to propose that semantic fields like possession, motion and location share the same functions. Verbs and prepositions may occur in various interrelated semantic fields. For further details see also Jackendoff (1990: 25), (2014). Ikegami (1982, 1987) points out the dissymmetry between expressions of 'giving' and 'receiving' in Japanese.

Note 3. If there is an A [=Agent], it becomes the subject; otherwise, if there is an I [=Instrument], it becomes the subject; otherwise, the subject is the $\mathrm{O}[=$ Objective, i.e., Theme/Patient] (Fillmore 1968: 33).

Note 4. I give the gloss only if there is no correspondence at all with English. 


\section{Macrothink}

International Journal of Linguistics

ISSN 1948-5425

2020, Vol. 12, No. 6

Note 5. I have glossed the prefixes of the verbs as in (14), where the verb provenire is formed of the prefix pro- and the verb venire.

Note 6. Folli (2001, 2008), Zubizzareta and Oh (2007), and Vietri (2019a) examine manner-of-motion verbs in Italian and Romance in detail.

Note 7. The authors analyze French; the Italian equivalents are mine.

Note 8. The term locatum was first used by Clark and Clark (1979) to refer to the entity whose location is described by the verb (Levin 1993:81).

Note 9. For a detailed discussion on the causal subject see Vietri (2017).

Note 10. It may happen that only the 'animate' direct object takes part in alternation, as in (31b). For a detailed discussion on distributional restrictions, see Vietri (2019b).

Note 11. In some cases there is no clear-cut difference between a reflexive construction and the marked unaccusative construction of a causative pair. A sentence like Maria si sporcò (Maria SI dirty.3SG.PST.IND. 'Maria got dirty') can be analyzed either as 'Maria got dirty by herself' or 'Maria got dirty with the mud splashed by the horse'.

Note 12. Mateu (2017) analyzes the locative alternation in v-framed and s-framed languages.

Note 13. The prefixes play a central role in denoting a source or a goal location, for details see Vietri (2019b). For a strict morphological analysis, the reader may refer to Grossmann and Rainer (2004).

Note 14. The gloss for the examples (61) and (62) highlights the morphological structure of the verbs (prefix-base noun.PersonNumberTenseMode), which have no correspondences at all in English.

Note 15. Native speaker 1 considers the English sentence (91) more dubious than (90).

Note 16. Native speaker 2 considers the English sentence in (99) dubious.

\section{Appendix}

Each class is represented as a matrix where each row corresponds to a verb and each column refers to a property. If a verb accepts a property, a "+" sign is placed at the intersection of the corresponding row and column. The columns indicating the Transitive-Intransitive alternation and the Subject Alternation are marked "+"if there is at least one sentence that takes part in that alternation. If a verb has more than one usage it is listed twice.

* This verb necessarily needs both source and goal PPs; none of them can be omitted.

** Bleaching effect: This verb has almost lost the meaning of the base noun. 


\begin{tabular}{|c|c|c|c|c|}
\hline $\begin{array}{l}\text { Class A } \\
\text { (Locatum-Location) }\end{array}$ & 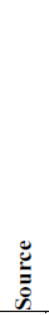 & $\overline{\tilde{B}}$ & 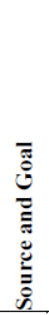 & 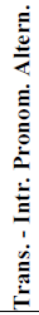 \\
\hline abbandonare & & + & & \\
\hline accogliere & & + & & \\
\hline accomodare & & + & & \\
\hline accompagnare & & + & & \\
\hline accostare & & + & & + \\
\hline accumulare & & + & & + \\
\hline adagiare & & + & & + \\
\hline addentrare & & + & & + \\
\hline affacciare & & + & & + \\
\hline agganciare & & + & & + \\
\hline allontanare & + & & & + \\
\hline allontanare & + & & & \\
\hline alzare & + & & & + \\
\hline
\end{tabular}

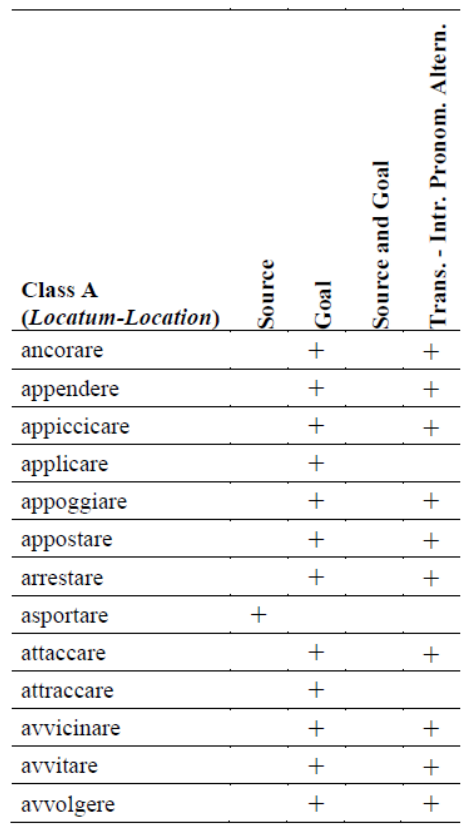

\begin{tabular}{|c|c|c|c|c|}
\hline $\begin{array}{l}\text { Class A } \\
\text { (Locatum-Location) }\end{array}$ & 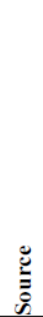 & $\bar{g}$ & 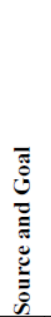 & 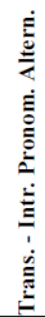 \\
\hline bagnare & & + & & \\
\hline barricare & & + & & + \\
\hline buttare & & & + & + \\
\hline cacciare & + & & & \\
\hline calare & & & + & + \\
\hline catapultare & & & + & + \\
\hline chiudere & & + & & + \\
\hline colare & & + & & \\
\hline collocare & & + & & + \\
\hline concentrare & & + & & + \\
\hline condurre & & + & & \\
\hline conficcare & & + & & + \\
\hline confinare & & + & & \\
\hline
\end{tabular}

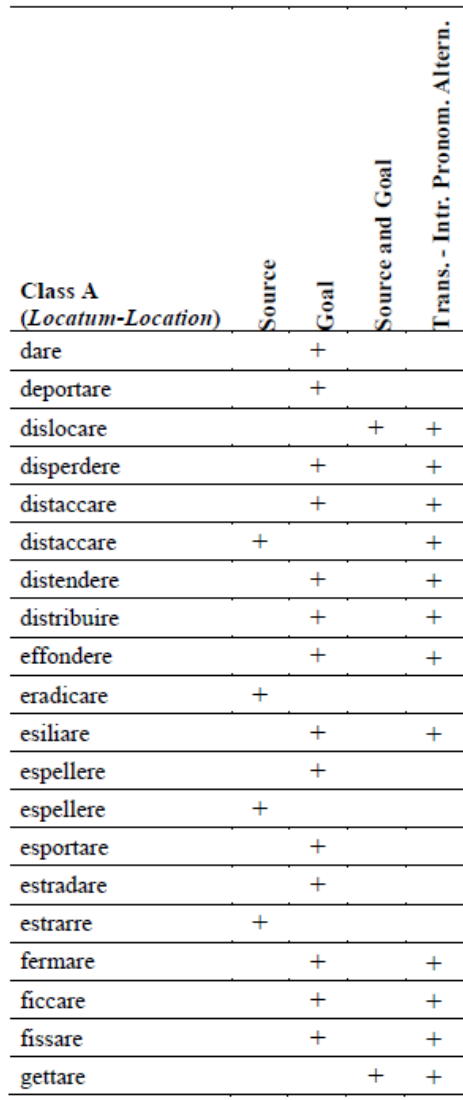

\begin{tabular}{|c|c|c|c|c|}
\hline $\begin{array}{l}\text { Class A } \\
\text { (Locatum-Location) }\end{array}$ & 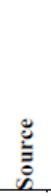 & $\overline{\tilde{g}}$ & 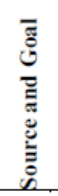 & 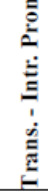 \\
\hline girare & & + & & \\
\hline grattare & + & & & \\
\hline immergere & & + & & + \\
\hline immettere & & + & & + \\
\hline importare & + & & & \\
\hline incagliare & & + & & + \\
\hline incatenare & & + & & + \\
\hline inchiodare & & + & & + \\
\hline incollare & & + & & + \\
\hline infilare & & + & & + \\
\hline infiltrare & & + & & + \\
\hline inseguire & & & + & \\
\hline inserire & & + & & + \\
\hline insinuare & & + & & + \\
\hline instillare & & + & & \\
\hline intanare & & + & & + \\
\hline introdurre & & + & & + \\
\hline intrufolare & & + & & + \\
\hline inviare & & + & & \\
\hline lanciare & & & + & + \\
\hline
\end{tabular}

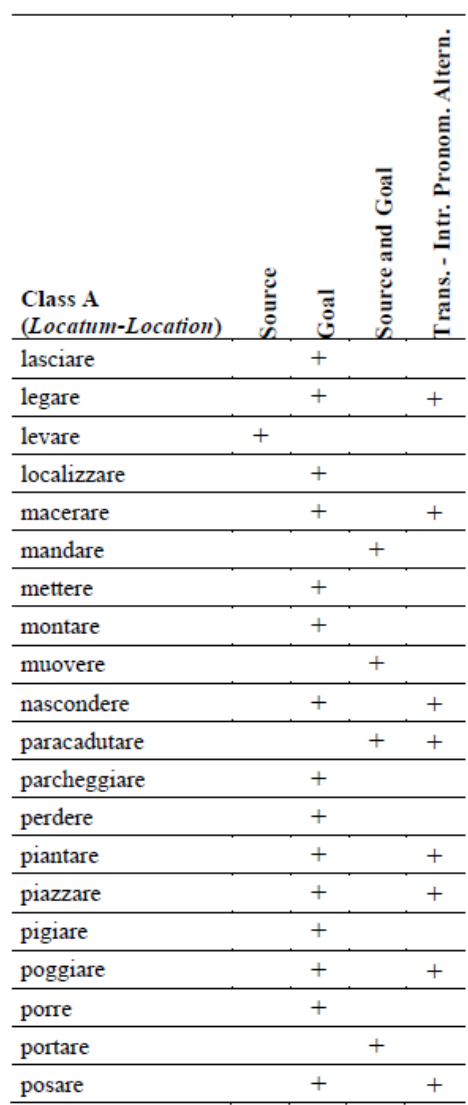




\begin{tabular}{|c|c|c|c|c|}
\hline $\begin{array}{l}\text { Class A } \\
\text { (Locatum-Location) }\end{array}$ & $\stackrel{\mathscr{E}}{\vdots}$ & $\overline{\mathrm{g}}$ & 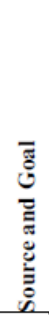 & 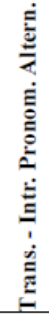 \\
\hline posizionare & & + & & + \\
\hline precipitare & & & + & \\
\hline premere & & + & & \\
\hline prendere & + & & & \\
\hline pressare & & + & & \\
\hline proiettare & & & + & + \\
\hline propagare & & + & & + \\
\hline puntare & & + & & \\
\hline raccattare & + & & & \\
\hline racchiudere & & + & & \\
\hline raccogliere & & + & & + \\
\hline raccogliere & & + & & \\
\hline raccogliere & + & & & \\
\hline radunare & & + & & + \\
\hline raggiungere & & + & & \\
\hline recare & & & + & + \\
\hline relegare & & + & & + \\
\hline ricacciare & & + & & + \\
\hline rimuovere & + & & & \\
\hline rinchiudere & & + & & + \\
\hline
\end{tabular}

\begin{tabular}{|c|c|c|c|c|}
\hline $\begin{array}{l}\text { Class A } \\
\text { (Locatum-Location) }\end{array}$ & $\stackrel{\mathscr{E}}{\vdots}$ & $\bar{g}$ & 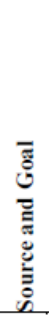 & 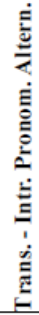 \\
\hline rintanare & & + & & + \\
\hline riunire & & + & & + \\
\hline riversare & & + & & + \\
\hline riversare & & & + & + \\
\hline rivolgere & & + & & \\
\hline rotolare & & + & & \\
\hline rovesciare & & + & & + \\
\hline sballottare* & & & + & \\
\hline sbalzare & & & + & \\
\hline sbattere & & + & & \\
\hline scacciare & + & & & \\
\hline scagliare & & & + & + \\
\hline scaraventare & & & + & + \\
\hline scaricare & & + & & \\
\hline scaricare & + & & & \\
\hline schiacciare & & + & & \\
\hline sciogliere & & + & & + \\
\hline sconficcare & + & & & \\
\hline scostare & + & & & + \\
\hline sdraiare & & + & & + \\
\hline
\end{tabular}

\begin{tabular}{|c|c|c|c|c|}
\hline $\begin{array}{l}\text { Class A } \\
\text { (Locatum-Location) }\end{array}$ & 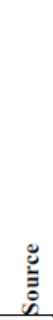 & $\overline{\tilde{E}}$ & 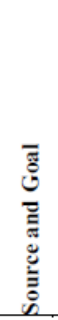 & 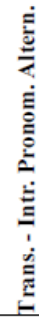 \\
\hline sedere & & + & & + \\
\hline segregare & & + & & + \\
\hline seguire & & + & & \\
\hline seppellire & & + & & \\
\hline sfilare & + & & & + \\
\hline sfrattare & + & & & \\
\hline sganciare & & & + & + \\
\hline sganciare & + & & & + \\
\hline sistemare & & + & & \\
\hline situare & & + & & + \\
\hline soffiare & & & + & \\
\hline sollevare & & & + & + \\
\hline sovrapporre & & + & & + \\
\hline spalare & + & & & \\
\hline spandere & & + & & + \\
\hline sparare & & + & & \\
\hline spargere & & + & & + \\
\hline spaziare & & + & & \\
\hline spingere & & + & & \\
\hline spostare & & & + & + \\
\hline
\end{tabular}

\begin{tabular}{|c|c|c|c|c|}
\hline $\begin{array}{l}\text { Class A } \\
\text { (Locatum-Location) }\end{array}$ & है & స్్ㅐ & 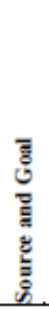 & 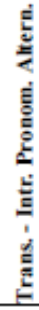 \\
\hline sradicare & + & & & + \\
\hline staccare & + & & & + \\
\hline stendere & & + & & + \\
\hline strappare & + & & & + \\
\hline strascinare & & & + & \\
\hline stringere & & + & & + \\
\hline strofinare & & + & & \\
\hline sversare & & + & & + \\
\hline tagliare & + & & & \\
\hline togliere & + & & & \\
\hline traghettare & & & + & \\
\hline trapiantare & & & + & + \\
\hline trasbordare & & & + & \\
\hline trascinare & & + & & \\
\hline trascinare & & & + & + \\
\hline trasferire & & & + & + \\
\hline trasportare & & & + & \\
\hline travasare & & & + & \\
\hline tuffare & & + & & \\
\hline versare & & & + & + \\
\hline
\end{tabular}

\begin{tabular}{|c|c|c|c|c|}
\hline $\begin{array}{l}\text { Class B } \\
\text { (Location-Locatum) }\end{array}$ & है & 퓽 & 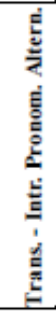 & 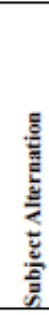 \\
\hline anredare & & + & & + \\
\hline bagnare & & + & + & + \\
\hline circondare & & + & & + \\
\hline colmare & & + & + & + \\
\hline colorare & & + & & + \\
\hline decorare & & + & & + \\
\hline dipingere & & + & & + \\
\hline disinfestare & + & & & \\
\hline gonfiare & & + & & + \\
\hline illustrare & & + & & + \\
\hline imbottire & & + & & + \\
\hline ingombrare & & + & & + \\
\hline intasare & & + & + & + \\
\hline inzeppare & & + & + & + \\
\hline inzuppare & & + & & + \\
\hline liberare & + & & & \\
\hline macchiare & & + & + & + \\
\hline omare & & + & & + \\
\hline popolare & & + & + & + \\
\hline
\end{tabular}

\begin{tabular}{|c|c|c|c|c|}
\hline $\begin{array}{l}\text { Class B } \\
\text { (Location-Locatum) }\end{array}$ & है & 풍 & 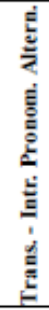 & 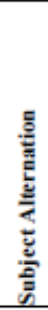 \\
\hline prosciugare & + & & + & \\
\hline ricopnire & & + & + & + \\
\hline nempire & & + & + & + \\
\hline nipulire & + & & + & \\
\hline nivestire & & + & + & + \\
\hline spogliare & + & & & \\
\hline svuotare & + & & + & + \\
\hline tingere & & + & + & + \\
\hline ungere & & + & + & + \\
\hline vuotare & + & & + & + \\
\hline
\end{tabular}




\begin{tabular}{|c|c|c|c|}
\hline $\begin{array}{l}\text { Class C } \\
\text { (Locative Alternation) }\end{array}$ & 巳̈ & స్ & 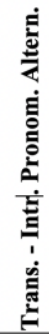 \\
\hline caricare & & + & \\
\hline cospargere & & + & + \\
\hline disseminare & & + & + \\
\hline pulire & + & & + \\
\hline ricamare & & + & \\
\hline schizzare & & + & + \\
\hline sgomberare & + & & + \\
\hline sgombrare & + & & + \\
\hline spalmare & & + & + \\
\hline spazzare & + & & \\
\hline spennellare & & + & + \\
\hline spolverare & & + & \\
\hline spruzzare & & + & + \\
\hline strofinare & & + & \\
\hline
\end{tabular}

\begin{tabular}{|c|c|c|c|c|}
\hline $\begin{array}{l}\text { Class D } \\
\text { (Locatum verbs) }\end{array}$ & 巳ั & ్ㅐㅇ & 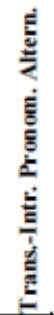 & 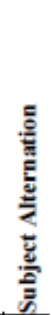 \\
\hline acciottolare & & + & & \\
\hline ammobiliare & & + & & + \\
\hline annotare & & + & & \\
\hline annuvolare & & + & + & + \\
\hline armare & & + & & + \\
\hline aromatizzare & & + & + & + \\
\hline asfaltare & & + & & + \\
\hline attrezzare & & + & & + \\
\hline brinare & & + & + & + \\
\hline colorare & & + & + & + \\
\hline decaffeinare & + & & & \\
\hline decolorare & + & & + & \\
\hline decorare & & + & + & + \\
\hline denocciolare & + & & & \\
\hline deodorare & + & & + & \\
\hline depilare & + & & + & \\
\hline derattizzare & + & & & \\
\hline desalare & + & & & \\
\hline desquamare & + & & + & \\
\hline deteinare & + & & & \\
\hline deviscerare & + & & & \\
\hline
\end{tabular}

\begin{tabular}{|c|c|c|c|c|}
\hline $\begin{array}{l}\text { Class D } \\
\text { (Locatum verbs) }\end{array}$ & $\stackrel{8}{8}$ & स्षु & 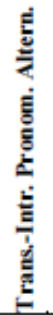 & 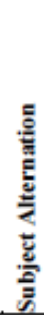 \\
\hline diliscare & + & & & \\
\hline disargentare & + & & & \\
\hline disanmare & + & & & \\
\hline disboscare & + & & & \\
\hline disincrostare & + & & + & \\
\hline disossare & + & & & \\
\hline dissalare & + & & & \\
\hline dissellare & + & & & \\
\hline eviscerare & + & & & \\
\hline foderare & & + & & + \\
\hline imbalsamare & & + & & \\
\hline imbandierare & & + & & + \\
\hline imbavagliare & & + & & + \\
\hline imbellettare & & + & + & + \\
\hline imbrigliare & & + & + & + \\
\hline imbrodolare & & + & + & + \\
\hline imburrare & & + & & \\
\hline impagliare & & + & & \\
\hline impaillettare & & + & + & \\
\hline impanare & & + & & + \\
\hline imparruccare & & + & + & \\
\hline
\end{tabular}

\begin{tabular}{|c|c|c|c|c|}
\hline $\begin{array}{l}\text { Class D } \\
\text { (Locatum verbs) }\end{array}$ & $\frac{8}{2}$ & हु & 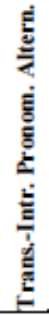 & 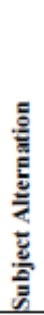 \\
\hline impelare & & + & + & + \\
\hline impellicciare & & + & + & \\
\hline impepare & & + & & + \\
\hline impidocchiare & & + & + & + \\
\hline impiumare & & + & & + \\
\hline impollinare & & + & + & + \\
\hline impolverare & & + & + & + \\
\hline impomatare & & + & + & + \\
\hline inargentare & & + & & + \\
\hline incamiciare & & + & & + \\
\hline incappottare & & + & + & + \\
\hline incappucciare & & + & + & + \\
\hline incapsulare & & + & & \\
\hline incartare & & + & & \\
\hline incatramare & & + & + & + \\
\hline incellofanare & & + & & + \\
\hline incerare & & + & & + \\
\hline incerottare & & + & + & \\
\hline inchiostrare & & + & + & + \\
\hline incipriare & & + & + & + \\
\hline incordare & & + & & \\
\hline
\end{tabular}




\begin{tabular}{|c|c|c|c|c|}
\hline $\begin{array}{l}\text { Class D } \\
\text { (Locatum verbs) }\end{array}$ & 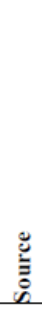 & $\overline{\tilde{F}}$ & 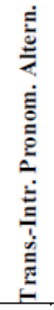 & 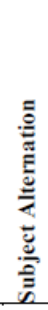 \\
\hline incorniciare & & + & & + \\
\hline incoronare & & + & & + \\
\hline incrostare & & + & + & + \\
\hline inerbire & & + & + & + \\
\hline infangare & & + & + & + \\
\hline infarinare & & + & + & \\
\hline infiocchettare & & + & + & + \\
\hline infiorare & & + & + & + \\
\hline informaggiare & & + & & \\
\hline infrascare & & + & & \\
\hline ingemmare & & + & + & + \\
\hline inghiaiare & & + & & + \\
\hline inghirlandare & & + & + & + \\
\hline ingigliare & & + & + & \\
\hline ingioiellare & & + & + & + \\
\hline ingrassare & & + & & + \\
\hline innevare & & + & + & + \\
\hline insabbiare & & + & + & + \\
\hline insalivare & & + & & \\
\hline insaponare & & + & + & + \\
\hline intonacare & & + & + & + \\
\hline
\end{tabular}

\begin{tabular}{|c|c|c|c|c|}
\hline $\begin{array}{l}\text { Class } \mathbf{D} \\
\text { (Locatum verbs) }\end{array}$ & 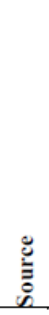 & $\bar{g}$ & 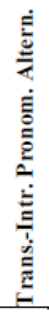 & 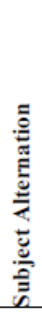 \\
\hline inverniciare & & + & & + \\
\hline inzaffirare & & + & + & \\
\hline inzuccherare & & + & & + \\
\hline minare & & + & & \\
\hline oliare & & + & + & + \\
\hline pavimentare & & + & & + \\
\hline pelare & + & & + & \\
\hline pepare & & + & & + \\
\hline piombare & & + & & \\
\hline profumare & & + & + & + \\
\hline rimboscare & & + & + & + \\
\hline salare & & + & & + \\
\hline sbavagliare & + & & & \\
\hline sbrigliare & + & & + & \\
\hline sbrinare & + & & + & \\
\hline sbrodolare & & + & + & + \\
\hline sbucciare & + & & + & \\
\hline sbudellare & + & & & \\
\hline sburrare & + & & & \\
\hline scappucciare & + & & + & \\
\hline scarabocchiare & & + & & \\
\hline
\end{tabular}

\begin{tabular}{|c|c|c|c|c|}
\hline $\begin{array}{l}\text { Class D } \\
\text { (Locatum verbs) }\end{array}$ & 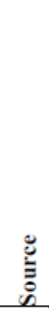 & $\overline{\tilde{g}}$ & 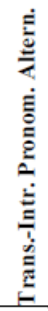 & 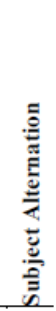 \\
\hline scartare & + & & & \\
\hline schiumare & + & & & \\
\hline scolorire & + & & + & \\
\hline scortecciare & + & & + & \\
\hline scotennare & + & & & \\
\hline scrostare & + & & + & \\
\hline scuoiare & + & & & \\
\hline selciare & & + & & \\
\hline sellare & & + & & \\
\hline sfoderare & + & & & \\
\hline sfogliare & + & & + & \\
\hline sfrondare & + & & + & \\
\hline sgrassare & + & & + & \\
\hline sminare & + & & & \\
\hline snocciolare & + & & & \\
\hline spellare & + & & + & \\
\hline spennare & + & & + & \\
\hline speziare & & + & & + \\
\hline spidocchiare & + & & + & \\
\hline spiumare & + & & + & \\
\hline spolverare & + & & + & \\
\hline
\end{tabular}

\begin{tabular}{|c|c|c|c|c|}
\hline $\begin{array}{l}\text { Class } D \\
\text { (Locatum verbs) }\end{array}$ & שू & है & 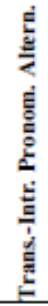 & 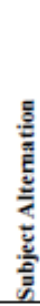 \\
\hline spulciare & + & & + & \\
\hline squamare & + & & + & \\
\hline stappare & + & & + & \\
\hline struccare & + & & + & \\
\hline svemiciare & + & & + & \\
\hline tappare & & + & + & + \\
\hline tappezzare & & + & & + \\
\hline truccare & & + & + & \\
\hline velare & & + & + & + \\
\hline verniciare & & + & & \\
\hline vestire & & + & + & + \\
\hline zavonare & & + & & + \\
\hline zuccherare & & + & & + \\
\hline
\end{tabular}

\begin{tabular}{|c|c|c|c|c|}
\hline $\begin{array}{l}\text { Class } \mathrm{E} \\
\text { (Location Verbs) }\end{array}$ & $\stackrel{\mathscr{E}}{\bar{n}}$ & 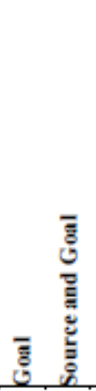 & 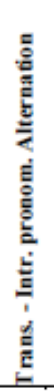 & 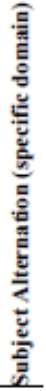 \\
\hline accampare & & + & + & \\
\hline accasermare & & + & + & \\
\hline accatastare & & + & + & \\
\hline aggomitolare & & + & & \\
\hline allineare & & + & & \\
\hline allocare & & + & & + \\
\hline alloggiare & & + & + & + \\
\hline ammassare & & + & + & \\
\hline ammucchiare & & + & + & \\
\hline archiviare & & + & & \\
\hline basare & & + & & \\
\hline cerchiare & & + & & \\
\hline cestinare & & + & & \\
\hline degusciare & + & & & \\
\hline depositare** & & + & & \\
\hline disarcionare & + & & & \\
\hline espatriare & + & & & \\
\hline esumare & + & & & \\
\hline imballare & & + & & \\
\hline
\end{tabular}

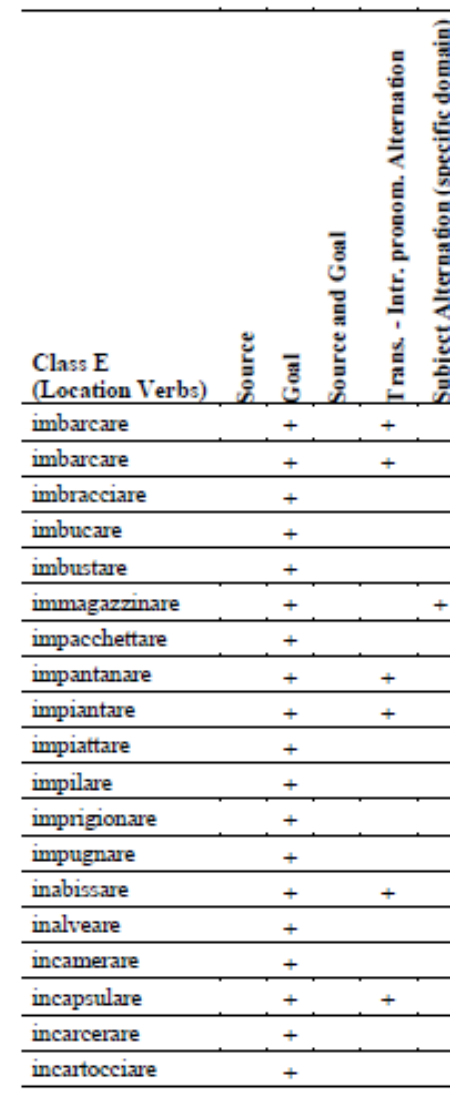



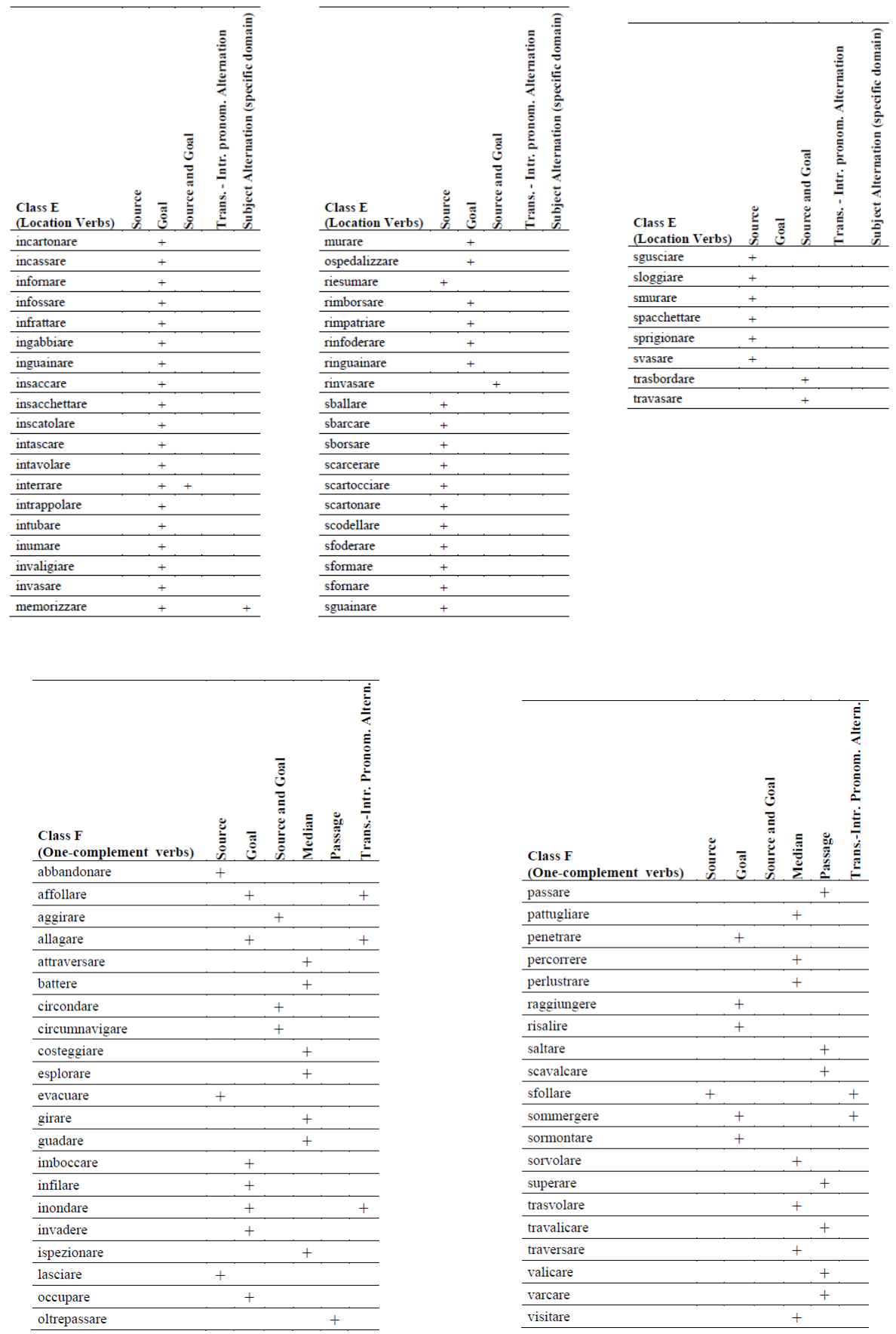

\section{Copyrights}

Copyright for this article is retained by the author(s), with first publication rights granted to the journal.

This is an open-access article distributed under the terms and conditions of the Creative Commons Attribution license (http://creativecommons.org/licenses/by/4.0/) 